\title{
Practical evaluation of method of porker meat classification based on criteria $\mathrm{pH}_{1}$ and $\mathrm{R}_{1}$
}

\section{Maria Koćwin-Podsiadła', Jolanta Kurył ${ }^{2}$ and W. Przybylski ${ }^{1}$}

\author{
'Higher Agricultural and Pedagogical School, Institute of Animal Breeding and Technology, \\ B. Prusa 14, 08-110 Siedlce. Poland \\ 'Institute of Genetics and Animal Breeding, Polish Academy of Sciences, \\ Jastrzębiec, 05-55/ Mroków, Poland
}

(Received 21 February 1994; accepted 12 May 1994)

\begin{abstract}
Examinations covered 1176 porkers of Polish Landrace breed. The fresh meat quality was evaluated on the basis of several physicochemical characteristics, determined in the muscle tissue of m. longissimus dorsi, 45 min and $24 \mathrm{~h}$ after slaughter. Polymorphism of blood proteins Phi, Po2 and Pgd, determined by genes linked to halothanc-sensitivity locus Hal, was tested electrophoreticaly. The frequency of occurence of $\mathrm{Phi}^{\mathrm{B}}-\mathrm{Po} 2^{\mathrm{S}}-\mathrm{Pgd}^{\mathrm{A}}$ (BSA) and $\mathrm{Phi}^{\mathrm{B}}-\mathrm{Po}^{\mathrm{S}}-\mathrm{Pgd}^{\mathrm{B}}$ (BSB) haplotypes in respective classes of porkers whose meat was classified as PSE, partly PSE, normal and DFD, conlirmed that the most useful method of classification of meat in Polish Landrace breed is method based on the following limit values of $\mathrm{pH}_{1}$ and $\mathrm{R}_{1}$ : $\mathrm{PSE}\left(\mathrm{pH}_{1}<6.0 ; \mathrm{R}_{1} \geqslant 1.09\right)$, partly PSE $\left(\mathrm{pH}_{1}<6.0\right.$; $\left.\mathbf{R}_{1}<1.09\right)$ normal $\left(\mathrm{pH}_{1} \geqslant 6.0 ; \mathrm{R}_{1}<1.09\right)$, DFD $\left(\mathrm{pH}_{1} \geqslant 6.0 ; \mathrm{R}_{1} \geqslant 1.09\right)$.

The diagnostics value of $\mathrm{pH}_{1}$ and $\mathrm{R}_{1}$ used for fresh meat quality evaluation was determined on the basis of coefficient of canonical correlation $\mathrm{C}^{\mathrm{R}}$. The correctness of method of meat quality evaluation was verified on the basis of quality of ham prepared using m. semimembranosus (I group-100 pigs) and m. semimembranosus, $m$. quadriceps femoris, m. biceps femoris (1I group-104 pigs). The verification of correctness of the method used confirmed that parameters $\mathrm{pH}_{1}$ and $\mathrm{R}_{1}$ determined in $m$. longissimus dorsi at $\mathbf{4 5}$ min post mortem allow to prognose the quality of ham conserved.
\end{abstract}

KEY WORDS: meat quality evaluation, methods, pigs

\section{INTRODUCTION}

Many methods have been presented in distinguishing meat with PSE and DFD. Despite the long-term investigation on the methods of meat classification, no criterion or criteria have been found allowing explicit and quick deter- 
mination of faulty meat resulting from genetic and physiological traits of an animal, related to a reaction of an organism to stressing factors.

The most frequent criteria of meat classification are:

- $\mathrm{pH}$ values determined in the MLD 45 min post mortem $\left(\mathrm{pH}_{\mathrm{l}}\right)$ allowing detection of PSE meat (Briskey and Wismer-Pedersen, 1961);

$-\mathrm{pH}_{45}$ and $\mathrm{pH}_{24}(24 \mathrm{~h}$ post mortem $)$ values, used to detect three clasess of meat: PSE, normal, DFD (Scheper, 1976; Wirth, 1985) or five clasess: PSE, partly PSE, normal, partly DFD, DFD (Kortz, 1986);

$-\mathrm{pH}$ values and IMP/ATP nucleotide ratio (R1) determined in the MLD 45 min post mortem, allowing to distinguish faulty PSE and DFD meat from normal (Honikel and Fischer, 1977; Koćwin-Podsiadła and Chmura-Janowiak, 1988; Koćwin-Podsiadła et al., 1992; Koćwin-Podsiadła and Kurył, 1992); - histochemical and histological traits of muscle tissue (Kłosowska et al., 1984).

In many countries pigs are selected on the basis of the halothane test which enables elimination of individuals with genetically conditioned defect of tissue membranes (homozygotes of $\mathrm{Hal}^{\mathrm{n}}$ allele determining susceptibility to halothane). Since, as it has been explicity found (Archibald and Imlah, 1985), meat revealing PSE and DFD is most often identified in halothane-susceptible individuals, the elimination of $\mathrm{Hal}^{\mathrm{n}}$ allele from a population is accompanied by a decrease in the frequency of occurence of faulty meat (Archibald and Imlah, 1985; Vögeli et al., 1984, 1985). Hal ${ }^{n}$ gene is linked with Phi, Po2 and Pgd genes controlling polymorphism of phosphohexose isomerase of blood erythrocytes postalbumin-2 in blood serum, 6-phosphogluconate dehydrogenase.

This study was aimed at evaluating the criteria $\mathrm{pH}_{1}$ and $\mathrm{R}_{1}$ used for porcine classification as well as its verification on the basis of physicochemical characteristics of fresh meat and quality of conserved ham.

\section{MATERIAL AND METHODS}

The studies were performed on the material comprising of 1176 porkers of Polish Landrace breed. The characteristics of meat quality were measured in $m$. longissimus dorsi at the last rib by the following methods:

$-\mathrm{pH}_{1}$ value was measured at $45 \mathrm{~min}$ and $\mathrm{pH}_{24}$ at $24 \mathrm{~h}$ post mortem in muscle homogenate ( $10 \mathrm{~g}$ of muscle was homogenized with $10 \mathrm{ml}$ of distilled water),

- the nucleotide ratio IMP/ATP was measured according to Honikel and Fisher (1977): $R_{1}$ at $45 \mathrm{~min}$ and $R_{24}$ at $24 \mathrm{~h}$ after slaughter,

- water-holding capacity (HWC) was determined according to Grau and Hamm (1952),

- drip loss was tested by the method of Prange et al. (1977), 
- the colour lightness was measured at $24 \mathrm{~h}$ after slaughter,

- activity of $\mathrm{LDH}$ and CPK was measured according to routine methods.

The limit values of $\mathrm{pH}_{1}$ and $\mathrm{R}_{1}$ for differentiation between normal, PSE, partly PSE and DFD meat have been applied as follows:

$\begin{array}{lcc}\text { class of meat } & \mathrm{pH}_{1} & \mathrm{R}_{1} \\ \text { normal } & \geqslant 6.0 & <1.09 \\ \text { PSE } & <6.0 & \geqslant 1.09 \\ \text { partly PSE } & <6.0 & <1.09 \\ \text { DFD } & \geqslant 6.0 & \geqslant 1.09\end{array}$

according to Honikel and Fischer (1977) in modification by Koćwin-Podsiadła et al. (1988).

The muscle $m$. semimembranosus was used for preparation ham of group I (100 pigs) and muscles, $m$. semimembranosus, $m$. biceps femoris and $m$. quadriceps femoris for preparation of hams of group II (104 pigs). These two groups of ham were made to check the possibility of prognosis of conserved ham quality on the basis of evaluation of $m$. longissimus dorsi characteristics.

The quality of ham of both groups, I and II, was evaluated on the basis of organoleptic parameters as follows: consistence, slice compactness (0-5 points) and gelatine content. The diagnostic value of $\mathrm{pH}_{1}$ and $\mathrm{R}_{1}$ criteria for fresh meat quality evaluation was determined on the basis of canonical correlation coefficient $C_{R}$. This analysis was performed on two groups of porkers: group I - 148 pigs, and group II - 261 pigs (according to Harris, 1975; Krzyśko and Ratajczyk, 1978).

Polymorphism of Phi, Po2 and Pgd blood proteins, determined by genes linked to halothane-sensitivity gene $\mathrm{Hal}^{\mathrm{n}}$, was tested according to Gahne and Juneja (1985). In each class of fresh meat, selected on the basis of the above discribed methods, the analysis of Phi- Po2-Pgd haplotypes (the appropriate system of alleles in relation to these loci) distribution was performed.

The frequency of occurence of Phi-Po2-Pgd haplotypes within meat classes was expressed as a per cent ratio. The significance of strenght association between occurence of different Phi-Po2-Pgd haplotypes and meat quality was evaluated on the basis of coefficient of linkage disequilibrum $D$, calculated according to Vögeli and Schwörer (1982).

\section{RESULTS AND DISCUSSION}

The tested pigs were divided into four groups: normal, PSE, partly PSE and DFD, on the basis of assessment of their meat quality. Phi-Po2-Pgd haplotypes have been defined for 352 individuals - triple homozygous or heterozygous in 
TABLE 1

Phi-Po2-Pgd haplotypes i Polish Landrace pigd with normal, partly PSE, PSE and DTD meat

\begin{tabular}{lcccc}
\hline Phi-Po2-Pg & \multicolumn{4}{c}{ Frequency of haplotypes, $\%$} \\
\cline { 2 - 5 } Haplotypes & normal & partly PSE & PSE & DFD \\
\cline { 2 - 5 } & 6.3 & 3.1 & 2.6 & 1.1 \\
\cline { 2 - 5 } & 1.1 & - & - & 3.3 \\
AFA & 0.4 & 3.1 & 1.3 & 1.1 \\
AFB & 0.8 & - & - & - \\
ASA & 45.4 & 35.9 & 30.3 & 33.3 \\
ASB & 29.1 & 29.7 & 15.8 & 30.0 \\
BFA & 6.1 & 10.9 & 26.3 & 16.7 \\
BFB & 10.8 & 17.2 & 23.7 & 14.4 \\
BSA & & & & \\
BSB & &
\end{tabular}

TABLF: 2

Linkage disequilibrum (D), standarized linkage disequilibrum $\left(D_{S}=F / D_{\max }\right)$, significance of $\mathrm{D}$ coefficient $(\mathrm{k})$ between genetic variants of Phi, Po2, Pgd and meat quality

\begin{tabular}{|c|c|c|c|c|c|c|}
\hline Group & Phi-Po2-Pg & meat & $\chi^{2}$ & D & $\mathrm{D}_{\mathrm{s}}$ & k \\
\hline \multirow[t]{3}{*}{ A } & AFA & normal & $5.66^{\mathrm{xx}}$ & 0.0234 & 0.59 & 4.97 \\
\hline & & PSE & 0.99 & -0.0200 & 0.13 & 1.33 \\
\hline & & DFD & 3.26 & -0.0420 & 0.29 & 3.59 \\
\hline \multirow[t]{3}{*}{ B } & BFA & normal & $9.69^{\mathrm{xx}}$ & 0.0251 & 0.22 & $9.25^{\mathrm{xx}}$ \\
\hline & & PSE & $4.30^{x}$ & -0.0306 & 0.26 & $5.02^{x}$ \\
\hline & & DFD & 2.72 & -0.0234 & 0.18 & 3.01 \\
\hline \multirow[t]{3}{*}{ C } & $\mathrm{BFB}$ & normal & 1.17 & 0.0098 & 0.10 & 1.15 \\
\hline & & PSE & $6.16^{x}$ & -0.0429 & 0.28 & $8.05^{\mathrm{xx}}$ \\
\hline & & DFD & 0.24 & 0.0072 & 0.04 & 0.23 \\
\hline \multirow[t]{3}{*}{ D } & BSA & normal & $25.18^{x x}$ & -0.0576 & 1.00 & $31.79^{\times \times x}$ \\
\hline & & PSE & $24.75^{x x}$ & 0.0641 & 0.30 & $14.43^{x \times x}$ \\
\hline & & DFD & $4.93^{x}$ & 0.0325 & 0.16 & 3.79 \\
\hline \multirow[t]{3}{*}{$\mathrm{E}$} & BSB & normal & $7.60^{\mathrm{xx}}$ & -0.0291 & 0.45 & $8.41^{\mathrm{xx}}$ \\
\hline & & PSE & $8.15^{\mathrm{xx}}$ & 0.0405 & 0.19 & $5.97^{x}$ \\
\hline & & DFD & 0.14 & 0.0059 & 0.03 & 0.13 \\
\hline
\end{tabular}

$x-P \leqslant 0.05 ; x x-P \leqslant 0.01 ; x x x-P \leqslant 0.001$

one of three linked loci. The distribution of Phi-Po2-Pgd haplotypes among four classes of pigs is shown in Table 1 . The associacion between AFB, ASB and ASA haplotypes and meat quality has not been analysed because of their low frequency in all groups of pigs (below $5 \%$ ). The relationship between each of AFA, BFA, BFB, BSA, BSB haplotypes and meat quality is shown in Table 2. A significant positive association has been observed between normal meat and 
haplotypes AFA and BFA (Table 2 A and B, respectively) as well as between PSE meat and both haplotypes BSA and BSB (Table 2 D and E, respectively). A positive association between DFD meat and BSA haplotypes also proved significant (Table $2 \mathrm{D}$ ), but the value of $\mathrm{k}=3.79$ indicated that coefficient $\mathrm{D}=0.0325$ has not been significantly different from zero $(\mathrm{P}>0.05)$.

Highly significant association between occurence of faulty meat (PSE and DFD) and $\mathrm{Phi}^{\mathrm{B}} \mathrm{Po} 2^{\mathrm{S}} \mathrm{Pgd}^{\mathrm{A}}$ (BSA) and $\mathrm{Phi}^{\mathrm{B}} \mathrm{Po}^{\mathrm{S}} \mathrm{Pgd}^{\mathrm{B}}$ (BSB) haplotypes linked to halothane gene $\mathrm{Hal}^{\mathrm{n}}$ confirmed the correctness of limit value of criteria $\mathrm{pH}_{1}$ and $\mathrm{R}_{1}$ used for meat quality evaluation in this study.

Earlier studies of Andresen (1987) also showed the significant association between occurence of faulty meat and both alleles $\mathrm{Phi}^{\mathrm{B}}$ and $\mathrm{H}^{\mathrm{a}}$ linked to $\mathrm{Hal}$ locus. Haplotypes BSA and BSB used in this study for verification of criteria $\mathrm{pH}_{1}$ and $R_{1}$ were shown to occur with significantly higher frequency within group of

TABLE 3

Determination distribution, $\%$ (explenatory variables $\mathrm{R}_{i}, \mathrm{pH}_{i}, \mathrm{pH}_{24}, \mathrm{R}_{24}$ )

\begin{tabular}{|c|c|c|c|c|c|c|c|c|c|}
\hline \multirow{3}{*}{ Characteristics } & & \multicolumn{8}{|c|}{ Canonical variable } \\
\hline & & \multicolumn{4}{|c|}{$\begin{array}{l}\text { I group } \\
\mathrm{n}=148\end{array}$} & \multicolumn{4}{|c|}{$\begin{array}{l}\text { II group } \\
n=261\end{array}$} \\
\hline & & $\mathrm{u}_{1}$ & $\mathrm{u}_{2}$ & $\mathrm{u}_{3}$ & $\mathrm{u}_{4}$ & $u_{1}$ & $\mathrm{u}_{2}$ & $\mathrm{u}_{3}$ & $\mathrm{u}_{4}$ \\
\hline $\mathbf{R}_{1}$ & $\mathrm{x}_{1}$ & 88.1 & 3.0 & 5.9 & 3.0 & 90.6 & 1.4 & 8.0 & 0.0 \\
\hline $\mathrm{pH}_{\mathrm{l}}$ & $\mathrm{x}_{2}$ & 98.5 & 1.3 & 0.2 & 0.0 & 96.1 & 3.9 & 0.0 & 0.0 \\
\hline $\mathrm{pH}_{24}$ & $\mathrm{x}_{3}$ & 6.9 & 76.7 & 16.2 & 0.2 & 87.8 & 2.3 & 9.6 & 0.3 \\
\hline \multirow[t]{2}{*}{$\mathrm{R}_{24}$} & $x_{4}$ & 32.4 & 16.2 & 51.3 & 0.0 & 30.2 & 10.6 & 58.7 & 0.5 \\
\hline & & $\mathrm{v}_{1}$ & $\mathrm{v}_{2}$ & $v_{3}$ & $\mathrm{v}_{4}$ & $v_{1}$ & $v_{2}$ & $v_{3}$ & $v_{4}$ \\
\hline $\begin{array}{l}\text { Colour } \\
\text { Lightnees, \% }\end{array}$ & $\mathrm{y}_{1}$ & 29.6 & 61.1 & 9.0 & 0.2 & 71.3 & 0.1 & 28.6 & 0.0 \\
\hline Drip loos, $g$ & $\mathrm{y}_{2}$ & 93.2 & 4.8 & 2.0 & 0.0 & 99.2 & 0.7 & 0.0 & 0.0 \\
\hline WHC & $y_{3}$ & 97.8 & 0.2 & 1.9 & 0.1 & 94.2 & 4.4 & 1.4 & 0.0 \\
\hline $\begin{array}{l}\text { Back fat } \\
\text { Thickness, mm }\end{array}$ & $\mathrm{y}_{4}$ & 40.2 & 8.3 & 49.6 & 2.0 & 38.1 & 52.5 & 1.4 & 8.0 \\
\hline $\begin{array}{l}\text { LDH activity } \\
\mathrm{U} / 1\end{array}$ & $y_{s}$ & 97.5 & 1.0 & 1.5 & 0.0 & 75.9 & 0.0 & 24.0 & 0.1 \\
\hline $\begin{array}{l}\text { CKP activity } \\
\mathrm{U} / 1\end{array}$ & $\mathrm{y}_{6}$ & 62.1 & 2.4 & 28.5 & 7.0 & 80.1 & 14.4 & 5.6 & 0.0 \\
\hline $\begin{array}{l}\text { Coefficient of canonio } \\
\text { correlation }\end{array}$ & $\mathrm{C}_{\mathrm{R}}$ & $0.660^{x \times}$ & $0.427^{\mathrm{xx}}$ & $0.311^{x}$ & 0.124 & $0.622^{x x}$ & $0.316^{\mathrm{xx}}$ & $0.254^{x}$ & 0.043 \\
\hline $\begin{array}{l}\text { Complex coefficient } \\
\text { of correlation }\end{array}$ & $\mathrm{R}_{\mathrm{c}}{ }^{2}$ & & 0.19 & & & & 0.14 & & \\
\hline
\end{tabular}

$\mathrm{x}-\mathrm{P} \leqslant 0.06 ; \mathrm{xx}-\mathrm{P} \leqslant 0.01$ 
halothane-sensitive pigs as compare to halothane-resistant animals (Gahne and Juneja, 1985; Nielsen et al., 1985; Kurył et al., 1992). Canonical analysis of significance of $\mathrm{pH}_{1}, \mathrm{R}_{1}, \mathrm{pH}_{24}$ and $\mathrm{R}_{24}$ criteria for meat quality evaluation showed that $\mathrm{pH}_{1}$ and $\mathrm{R}_{1}$ were most useful as compared to both traits $\mathrm{pH}_{24}$ and $\mathrm{R}_{24}$ (Table $3)$. The comparison of complex coefficients of correlation $\left(\mathrm{R}_{\mathrm{c}}{ }^{2}\right)$ showed that traits $\mathrm{pH}_{1}$ and $\mathbf{R}_{1}$ were a slightly more useful for meat quality diagnosis as compared to both criteria $\mathrm{pH}_{1}$ and $\mathrm{pH}_{24}$ (Table 4 and 5).

The verification of correctness of the used method for meat quality evaluation was also performed on the basis of quality of meat product (hams) (Table 6). Low (1.56 points) and simultaneously 2.24 fold lower value of parameters of ham quality, evaluated for product prepared using faulty muscles, as compare to quality of ham formed using normal meat (3.88 points), confirmed the correctness of criteria $\mathrm{pH}_{1}$ and $\mathrm{R}_{\mathrm{l}}$. They can be considered as criteria for porcine quality classification. The presented results (Table 6) showed that the values of $\mathrm{pH}_{1}$ and $\mathrm{R}_{1}$ determined in $m$. longissimus dorsi at 45 min post mortem allow to prognose the quality of ham produced using $m$. semimembranosus, m. biceps femoris and $m$. quadriceps femoris.

TABLE 4

Determination distribution, $\%$ (explenatory variables $\mathrm{R}_{1}$ and $\mathrm{pH}_{1}$ )

\begin{tabular}{|c|c|c|c|c|c|}
\hline \multirow{3}{*}{ Characteristics } & & \multicolumn{4}{|c|}{ Canonical variablc } \\
\hline & & \multicolumn{2}{|c|}{$\begin{array}{l}\text { I group } \\
\mathrm{n}=148\end{array}$} & \multicolumn{2}{|c|}{$\begin{array}{l}\text { II group } \\
n=261\end{array}$} \\
\hline & & $\mathbf{u}_{1}$ & $\mathrm{u}_{2}$ & $\mathbf{u}_{1}$ & $\mathrm{u}_{2}$ \\
\hline $\mathbf{R}_{1}$ & $\mathrm{x}_{1}$ & 95.8 & 4.2 & 94.5 & 5.5 \\
\hline \multirow[t]{2}{*}{$\mathrm{pH}_{1}$} & $x_{2}$ & 100.0 & 0.0 & 97.7 & 2.3 \\
\hline & & $v_{1}$ & $\mathrm{v}_{2}$ & $v_{1}$ & $v_{2}$ \\
\hline $\begin{array}{l}\text { Colour } \\
\text { Lightness, \% }\end{array}$ & $\mathrm{y}_{1}$ & 72.6 & 27.4 & 90.7 & 9.3 \\
\hline Drip loss, $\mathrm{g}$ & $\mathrm{y}_{2}$ & 99.9 & 0.1 & 99.7 & 0.3 \\
\hline WHC & $\mathrm{y}_{3}$ & 99.8 & 0.2 & 92.2 & 7.8 \\
\hline $\begin{array}{l}\text { LDH activity } \\
\mathrm{U} / 1\end{array}$ & $\mathrm{y}_{5}$ & 99.9 & 0.1 & 95.3 & 4.7 \\
\hline $\begin{array}{l}\text { CPK activity } \\
\mathrm{U} / 1\end{array}$ & $y_{6}$ & 96.6 & 3.4 & 96.2 & 3.8 \\
\hline $\begin{array}{l}\text { Coefficient of } \mathrm{c} \\
\text { correlation }\end{array}$ & \multicolumn{4}{|c|}{ Coefficient of canonical } & $0.280^{x x}$ \\
\hline $\begin{array}{l}\text { Complex coeffi } \\
\text { correlation }\end{array}$ & $\mathrm{R}_{\mathrm{c}}^{2}$ & & & & \\
\hline
\end{tabular}

$\mathrm{xx}-\mathrm{P} \leqslant 0.01$ 
TABLE 5

Determination distribution, \% (explanatory variables $\mathbf{R}_{1}$ and $\mathrm{pH}_{1}$ )

\begin{tabular}{|c|c|c|c|c|c|}
\hline \multirow{3}{*}{ Characteristics } & & \multicolumn{4}{|c|}{ Canonical variable } \\
\hline & & \multicolumn{2}{|c|}{$\begin{array}{l}\text { I group } \\
n=148\end{array}$} & \multicolumn{2}{|c|}{$\begin{array}{l}\text { II group } \\
n=261\end{array}$} \\
\hline & & $\mathrm{u}_{\mathrm{I}}$ & $\mathrm{u}_{2}$ & $\mathbf{u}_{\mathrm{t}}$ & $\mathrm{u}_{2}$ \\
\hline $\mathbf{R}_{1}$ & $x_{1}$ & 100.0 & 0.0 & 99.8 & 0.2 \\
\hline \multirow[t]{2}{*}{$\mathrm{pH}_{1}$} & $x_{2}$ & 1.7 & 98.3 & 96.0 & 4.0 \\
\hline & & $v_{1}$ & $v_{2}$ & $\mathbf{v}_{1}$ & $v_{2}$ \\
\hline $\begin{array}{l}\text { Colour } \\
\text { Lightness, \% }\end{array}$ & $y_{1}$ & 16.7 & 83.3 & 93.4 & 6.6 \\
\hline Drip loss, $\mathbf{g}$ & $y_{2}$ & 93.9 & 6.1 & 100.0 & 0.0 \\
\hline WHC & $\mathrm{y}_{3}$ & 96.8 & 3.2 & 99.9 & 0.1 \\
\hline $\begin{array}{l}\text { LDH activity } \\
\mathrm{U} / 1\end{array}$ & $y_{s}$ & 98.7 & 1.3 & 94.1 & 5.9 \\
\hline $\begin{array}{l}\text { CPK activity } \\
\mathrm{U} / 1\end{array}$ & $y_{6}$ & 93.8 & 6.2 & 98.5 & 1.5 \\
\hline $\begin{array}{l}\text { Coefficient of c } \\
\text { correlation }\end{array}$ & \multicolumn{4}{|c|}{ Coefficient of canonical } & 0.123 \\
\hline $\begin{array}{l}\text { Complex coeffic } \\
\text { correlation }\end{array}$ & $\mathbf{R}_{c^{2}}$ & & & & \\
\hline
\end{tabular}

$\mathbf{x x}-\mathbf{P} \leqslant 0.01$

TABLE 6

Ham evaluation in the quality classes

\begin{tabular}{lccccc}
\hline Quality class & Group & \multicolumn{3}{c}{ Parameters } \\
\cline { 3 - 5 } & I $\mathrm{n}=100$ & consistence & slice compactness & gelatine \\
& II & $\mathrm{n}=104$ & (points) & (points) & $(\%)$ \\
mean sd & mean sd & \\
\hline PSE & & I & $1.8 \pm 0.29$ & $1.5 \pm 0.50$ & 1.6 \\
Partly PSE & II & $1.6 \pm 0.55$ & $1.2 \pm 0.45$ & 0.7 \\
& I & $1.5 \pm 0.50$ & $1.3 \pm 0.57$ & 1.2 \\
Normal & II & $1.7 \pm 0.67$ & $2.6 \pm 0.89$ & 0.3 \\
& I & $3.5 \pm 0.00$ & $3.3 \pm 0.29$ & 1.4 \\
DFD & II & $4.5 \pm 0.50$ & $4.2 \pm 0.91$ & 0.5 \\
& i & $0.8 \pm 0.29$ & $1.0 \pm 0.00$ & 1.6 \\
& II & - & - & - \\
\hline
\end{tabular}




\section{REFERENCES}

Andresen E., 1987. Selection against PSS by means of blood typing. In: Evaluation and Control of Meat Quality in Pigs - A Seminar in the CEC Agricultural Rescarch Programme, Dublin (Ireland) 1985 In: P.V. Tarrant, G. Eikelenboom and G. Monin (Editors), Martinus Nijhoff Publ., Dordrecht, Boston, Lancaster, pp. 317-327

Archibald A.L., Imlah P., 1985. The halothane sensitivity locus and its linkage relationship. Anim. Blood Grps. Biochem. Genet. 16, 253-263

Briskey E.J., Wismer-Pedersen J., 1961. Biochemistry of pork muscle structure. I. Rate of anaerobic glycolysis and temperature change versus the apparent structure of muscle tissue. J. Food Sci. $26,297-305$

Gahne B., Juneja R.K., 1985. Prediction of the halothane (Hal) genotypes of pigs by deducing Hal, Phi, Po2, Pgd haplotypes of parents and offspring: results from a large- scale practice in Swedish breeds. Anim. Blood Grps. Biochem. Genet. 16, 265-283

Grau R., Hamm R., 1952. Eine cinfache Methode zur Bestimmung der Wasserbindung im Fleisch. Fleischwirtschaft 4, 295-297

Harris R.J., 1975. A primer of multivariablc statistics. Academic Press, New York

Honikel K.O., Fischer H., 1977. A rapid method for the detection of PSE and DFD porcine muscles. J. Food Sci. 42, 1633-1636

Kłosowska D., Kłosowski B., Grajewska S., Kortz J., 1984. Histological and histochemical characteristic of PSE muscles. Proceedings of Scientific Meeting. "Biophysical PSE - Muscle Analysis", Vicnna, A-6, 41-63

Koćwin-Podsiadła M., Chmura-Janowiak M., 1988. The ratio of IMP/ATP nucleotides and the pH value determined in 45 min after slaughter applied to evaluate the quality of fatness meat. VIth World Conference of Animal Production, Helsinki, Proc. 106

Koćwin-Podsiadla M., Kurył J., 1992. Comparative analysis of selected methods of classification of porker meat on the basis of frequency of Phi-Po2-Pgd haplotypes. Anim. Sci. Pap. Rep. 8, $25-37$

Koćwin-Podsiadła M., Kurył J., Dvorak J., 1994. 'The association between phenotypes of the Phi, Po2 and Pgd systems and meat quality in Polish Landrace pigs. Anim. Sci. Pap. Rep. (in press)

Koćwin-Podsiadła M., Zaremba W., Chmura-Janowiak M., 1988. The determination of the limit value of IMP/ATP and its application to the evaluation of pork. XIX Conference Science: "Postępy technologii w rozwoju produkcji żywności", Komitet Techn. i Chemii Żywności PAN, S/crecin, p. 43

Kortz J., 1986. Synthetic marker for meat quality in pork as a cryterium for differentiating healthy muscle, PSE i DFD (using boars and barrows as experimentals) (in Polish). Thesis Nr 100, Agric. University of Szczecin.

Krzyśko M., Ratajczyk W., 1978. Canonical analysis (in Polish). Listy biometr. 65-67, 1 46

Kurył J., Zurkowski M., Wróblewski T., 1992. Hal" gene determining halothane sensitivity of pigs in the group of linked loci. II. Coefficients of linkage disequilibrum between loci and haplotypes most frequency occuring with $\mathrm{Hal}^{\mathrm{n}}$ gene in Norwegian Landrace pigs. Anim. Sci. Pap. Rep. 8 , $15-23$

Niclsen P.B., Hyldgaard-Jensen J., Jrgensen P.F., 1985. The Phi-Hal-S-H-Po2-Pgd complex in Danish pig breeds. Anim. Blood Grps. Biochem. Genet. 16, Suppl. 1, 80

Prange H.. Jugert L., Scharner E., 1977. Untersuchungen zur Muskelfleischqualität beim Schwein. Arch. Exp. Vet. Med. (Leipzig) 2, 235-248

Scheper J., 1976. Investigation on the frequency of PSE and DFD in pork. Proceedings of 3rd International Conference: Production and Disease in Farm Animals. Wageningen, Netherlands. p. 141-146 
Vögeli P., Schwörer D., 1982. Kopplungsungleichgewicht rwischen dem Malignen Hyperthermie Syndrom (MHS), Halothanempfinlichkeit und den Phänotypen des H-Blutgruppensystems und des PHI-Enzymsystems beim Schweizerischen Verdelten Landschwein. Züchtungskunde $54,124-130$

Vögeli P., Söchwörer D., Kühne R., Wysshaar M., 1985. Trends in economic traits, halothane sensitivity, blood groups and enzyme systems of Swiss Landrace and Large White pigs. Anim. Grps. Biochem. Genet. 16, 285-296

Vögeli P., Stranzinger G., Schneebeli H., Hagger C., Künzi N., Gerwig C., 1984. Relationship between the $\mathrm{H}$ and A-O blood types, phosphohexose isomerase and 6- phosphogluconate dehydrogenase red cell enzyme systems and halothane sensitivity and economic traits in superior and an inferior selection line of Swiss Landrace pigs. J. Anim. Sci. 59, 1440-1450

Wirth F., 1985. Technologie der Verarbeitung von Fleisch mit abweichender Beschaftenheit. Schweiz. Arch. Ticrhcilkd. 127, 83-97

\section{STRESZCZENIE}

Praktyczna ocena metod klasyfikacji mięsa tuczników (porkerów) na podstawie $\mathrm{pH}_{1}$ i $\mathbf{R}_{1}$

Materiał badawczy stanowiło 1176 tuczników (porkerów) rasy polskiej białcj zwisłouchej. Jakość miçsa oceniano na podstawie wskaźników fizykochemicznych oznaczanych w tkance $m$. longissmus dorsi w 45 min i 24 godz. po uboju. Poliformizm białek krwi Phi, Po2 i Pgd, determinowanych przez geny związane $z$ reagującym na halotan locus $\mathrm{Hal}$, oznaczano elektroforetycznie. Częstotliwość występowania halotypów $\mathrm{Phi}^{\mathrm{B}}-\mathrm{Po} 2^{\mathrm{S}}-\mathrm{Pgd}^{\wedge}(\mathrm{BSA})$ oraz Phi ${ }^{\mathrm{B}}-\mathrm{Po} 2^{\mathrm{S}}-\mathrm{Pgd}^{\mathrm{B}}(\mathrm{BSB})$ w grupach tuczników, których mięso zakwalifikowano jako PSE, częściowo PSE, normalne i DFD potwierdza, że najodpowiedniejszą metodą oceny jakości mięsa świń rasy polskiej białej zwisłouchej jest metoda oparta na następujących granicznych wartościach $\mathrm{pH}_{1}$ i $\left.\mathrm{R}_{1}: \mathrm{PSE}\left(\mathrm{pH}_{1}<6.0\right) ; \mathrm{R}_{1} \geqslant 1.09\right)$, częściowo PSE $\left.\left(\mathrm{pH}_{1} \geqslant 6.0\right) ; \mathrm{R}_{1}<1.09\right)$, normalnie $\left.\left(\mathrm{pH}_{1} \geqslant 6.0\right) ; \mathrm{R}_{1}<1.09\right)$ oraz DFD $\left.\left(\mathrm{pH}_{1} \geqslant 6.0\right) ; \mathrm{R}_{1} \geqslant 1.09\right)$.

Wartości pH $\mathrm{H}_{1}$ i $\mathrm{R}_{1}$, przyjęte do oceny jakości mięsa, potwierdzono na podstawie wyników oceny s7ynki przygotowanej z. m. semimembranosus (grupa I - 100 świń) oraz z m. semimembranosus, $m$. quadriceps femoris i $m$. biceps femoris (grupa II - 104 świnie). Otrzymane wyniki wskazują, że wartości $\mathrm{pH}_{4}$ i $\mathrm{R}_{1}$, oznaczone $\mathrm{w}$ m. longissimus dorsi $\mathrm{w} 45 \mathrm{~min}$ po uboju, pozwalają na przewidywanie jakości szynki konserwowej. 